\title{
Can a psychiatrist be helpful for a cardiologist?
}

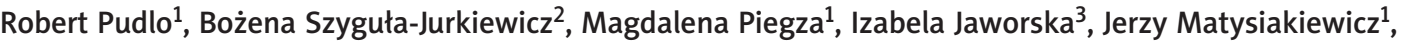 \\ Marian Zembala ${ }^{4}$ \\ 1Department of Psychiatry, Medical University of Silesia, Tarnowskie Góry, Poland \\ ${ }^{2}$ Third Department of Cardiology, Medical University of Silesia, Silesian Center for Heart Diseases, Zabrze, \\ Poland \\ ${ }^{3}$ Silesian Center for Heart Diseases, Zabrze, Poland \\ ${ }^{4}$ Department of Cardiac Surgery and Transplantation, Medical University of Silesia, Silesian Center for Heart Diseases, Zabrze, \\ Poland
}

Kardiochirurgia i Torakochirurgia Polska 2013; 10 (4): 425-429

\begin{abstract}
The paper presents four cases of mental disorders in cardiac patients. The first patient, treated for decompensated heart failure, continued to report coronary-like symptoms despite significant improvement of heart contractility. The second one underwent artificial pacemaker implantation due to bradycardia and heart block. The patient still suffered from distinct weakness with lowered mood. In the third case, a patient with long-term ischemic heart disease underwent successful invasive treatment for myocardial infarction, but after a few months his symptoms relapsed in the form of what he himself interpreted as angina pectoris. The last described patient was referred by her GP because of breathing difficulties and fatigue. In all the described cases, depression was diagnosed, and successful psychiatric treatment was implemented.

Discussion: In all the described cases, the symptoms persisted and worsened the patients' comfort despite achieving objective improvement. This alarmed the attending physicians and could have resulted in unnecessary treatment modifications. Paying attention to the psychopathological aspects of the heart diseases enabled the physicians to diagnose the present mental disorders, employ efficacious treatment, and significantly improve the patients' comfort.
\end{abstract}

Key words: consultation-liaison psychiatry, depression, somatoform disorders.

\section{Introduction}

The relations between psychiatry and cardiology are a frequent topic of study. Researchers have noted the common pathogenetic mechanisms of atherosclerosis and depression, the relation between sudden cardiac death

\section{Streszczenie}

W pracy przedstawiono cztery przypadki zaburzeń psychicznych u chorych kardiologicznych. Pierwsza opisana pacjentka była leczona z powodu zdekompensowanej niewydolności serca. Mimo poprawy obiektywnej zgłaszała szereg objawów imitujących niewydolność krążenia. Drugiej, z powodu bradykardii i bloku przedsionkowo-komorowego, wszczepiono sztuczny stymulator serca. Mimo to pacjentka odczuwała bardzo wyraźne osłabienie połączone z obniżonym nastrojem. Trzeci pacjent, z wieloletnią chorobą niedokrwienną serca, został poddany inwazyjnemu leczeniu zawału z dobrym skutkiem, a po kilku miesiącach przeżył nawrót dolegliwości, które sam interpretował jako stenokardialne. Ostatnia chora została skierowana z powodu duszności, zmęczenia i małej tolerancji wysitku. We wszystkich opisanych przypadkach rozpoznano zaburzenia depresyjne lub depresyjno-lękowe i wdrożono leczenie psychiatryczne, uzyskując poprawę.

Komentarz: We wszystkich przypadkach, mimo prawidłowego leczenia kardiologicznego i obiektywnej poprawy, utrzymywały się dolegliwości, które pogarszały jakość życia i mogły być przyczyną zbędnych badań diagnostycznych lub modyfikacji leczenia. Zwrócenie uwagi na psychopatologiczne elementy obrazu klinicznego pozwoliło na ustalenie rozpoznania zaburzeń psychicznych i skuteczne leczenie.

Słowa kluczowe: psychiatria konsultacyjna, depresja, zaburzenia somatoformiczne.

and anxiety [1-5], the influence of anxiety on the risk of coronary artery disease [6], the influence of depression on mortality following myocardial infarction and cardioverterdefibrillator implantation [7], as well as cognitive impairments following cardiac surgery procedures [8]. 
There appears, however, to be a disparity between the attitude of researchers, who continue to analyze the relations between psychiatry and cardiology with ever greater precision, and everyday medical practice, in which a patient with a mental disorder still poses serious diagnostic and therapeutic problems when referred to a cardiologist [9]. Some physicians also commit the error of naturalism, deeming the symptoms of depression to be a normal reaction to being sick $[10,11]$, while depression and/or anxiety syndromes are in fact concomitant diseases that require treatment, just as an abscess requires medical attention even though it is a "natural" reaction to bacterial infection.

The case studies below present four examples of mental disorders in cardiac patients. They are followed by an attempt to pinpoint their common features and provide basic rules of conduct.

\section{Case studies}

Mrs. J., aged 41, was admitted to the Silesian Center for Heart Diseases due to symptoms of decompensated heart failure (NYHA functional class III/IV). Echocardiographic examination revealed substantial impairment of left ventricular systolic function (left ventricular ejection fraction was approx. 15\%). Biopsy examination revealed signs of chronic persistent myocarditis. The patient received an optimal pharmacological treatment for heart failure, which included a converting enzyme inhibitor and a beta-blocker in gradually increased doses, as well as spironolactone and furosemide. After 2 months of treatment (conducted initially at the hospital, and later at the outpatient clinic), the patient's condition improved significantly, but the patient continued to suffer from troublesome subjective complaints in the form of increased fatigability, sleep disorders, anxiety, and dyspnea. The patient expected further cardiac diagnostics and a change of treatment; however, the conducted interview revealed that, six months before hospitalization, the patient experienced similar symptoms in combination with loss of interest in life, increased anxiety, and deep sadness, which prompted her to consult a psychiatrist, who diagnosed her with a depressive episode. The patient was encouraged to resume psychiatric treatment. A consulting psychiatrist prescribed venlafaxine (75-150 mg/day) and mianserin (30 mg/day), and recommended group therapy. The patient received simultaneous cardiological and psychiatric treatment, achieving a significant subjective improvement and retaining good left ventricular function. A follow-up examination conducted after two years revealed left ventricular ejection fraction at the level of $45 \%$ and minimal subjective complaints.

Mrs. A., aged 51, was admitted to the cardiology clinic due to vertigo and lightheadedness. The ailments had persisted for approximately six months and their intensity was increasing. The patient was weakened and complained of anxiety states, insomnia during the night, and somnolence during the day. Thyroid gland hypofunction was excluded. ECG revealed bradycardia, second-degree atrioventricular block, and ventricular escape rhythm with the frequency of
40 beats per minute (bpm). The patient underwent urgent artificial cardiac pacemaker implantation. After the procedure, the patient continued to suffer from the ailments; she was prone to crying and complained of insomnia, irritation, and trembling. When the patient was informed of a planned head CT examination, she went into an episode of severe anxiety and crying. A similar episode occurred after several days without an apparent reason. An interview was conducted, revealing that, for the past months, the patient had been caring after her father, who ultimately died of a brain tumor; the information concerning the CT examination invoked associations with the disease of her father. Moreover, the patient had been suffering from nightmares since the pacemaker implantation.

A consulting psychiatrist diagnosed her with mixed depressive and anxiety disorders and prescribed tianeptine 3 $x 12.5 \mathrm{mg}$. After three weeks, the intensity of the patient's anxiety subsided; after a further three weeks, the patient's mood improved, but she continued to complain of lack of energy. After four months, the mental condition of the patient was similar to her premorbid condition. Antidepressant therapy was continued.

Mr. F., aged 71, who had been treated for many years due to ischemic heart disease and had undergone a percutaneous coronary intervention 13 years earlier, was admitted to the cardiology clinic due to substernal chest pains, which had lasted for 3 hours, and decreased only slightly after taking nitroglycerin. Electrocardiographic examination (ECG) revealed a recent myocardial infarction of the anterior wall with ST-segment elevation. Urgent coronarography was performed, revealing a proximally amputated left anterior descending (LAD) branch of the left coronary artery. The patency of the vessel was restored mechanically, and balloon angioplasty was performed in combination with stent implantation within the lesion. After the procedure, the patient did not suffer from any complications; he was successfully rehabilitated and, subsequently, treated on an outpatient basis. After eight months, he began to experience recurring chest pains, even though a conducted cardiac stress test demonstrated good tolerance of exertion, and ECG showed no ischemic changes. The values of arterial blood pressure, measured multiple times, were normal, and the heart rate at rest was approximately $60 \mathrm{bpm}$. A detailed interview revealed sleep disorders in the form of early waking, as well as lowered mood, increased irritability, anxiety, health concerns, reduced life activity, and pessimistic ruminations about the future. Citalopram was prescribed at a dose increasing up to $40 \mathrm{mg} /$ day. After 6 weeks a minimal improvement was observed with regard to mood; as the results were not satisfactory, the medication was changed to escitalopram at a dose of up to $15 \mathrm{mg} /$ day. After the next 4 weeks, marked improvement was observed: the ailments within the chest subsided, and irritability was reduced. However, sleep disorders and reduced activity persisted. After 12 weeks of treatment, medication was changed once more, this time to sertraline (up to $100 \mathrm{mg} /$ day), achieving sig- 
nificant improvement within 8 weeks. The therapy was maintained for an indefinite time.

Mrs. H., aged 77, was referred to the cardiology clinic by her primary care physician due to dyspnea, feelings of fatigue, low exercise tolerance, vertigo, lightheadedness, and palpitations. The patient had been efficaciously treated for arterial hypertension for the past several years; she had also been taking amitriptyline for depression, dosed at $100 \mathrm{mg} /$ day, for the past 6 weeks. Physical examination did not reveal any swelling on the lower extremities; arterial pressure was 130/80 mm Hg, no congestion was observed above the lung fields, and the heart rate was arrhythmic with approximately $80 \mathrm{bpm}$. ECG revealed signs of left ventricular hypertrophy, as well as numerous extrastimuli of ventricular origin. Echocardiographic examination demonstrated good left ventricular systolic function (left ventricular ejection fraction 60\%) and left ventricular wall hypertrophy (IVSD: $1.3 \mathrm{~cm}$, LVPWD: $1.3 \mathrm{~cm}$ ). Laboratory investigation revealed no pathologies. As the antidepressant therapy was ineffective, a decision concerning further treatment had to be made. The employed (sub-therapeutic) antidepressant dose was well tolerated by the patient, but increasing it to a therapeutic level was considered too risky due to the age of the patient and the physical strain she was under. The amitriptyline treatment was discontinued and replaced with sertraline at the dose of $50 \mathrm{mg} /$ day. After 4 weeks, the patient's condition began to improve. Significant improvement of her mental condition was achieved after 12 weeks of treatment.

\section{Discussion}

All the case studies presented above originate from the Silesian Center for Heart Diseases. The first three have clear common features: in spite of proper cardiac treatment and an objective improvement of each patient's condition, clear and troublesome ailments persisted, worsening the patient's quality of life and alarming the physicians; this could have resulted in needless diagnostic tests or - similarly redundant - modifications in the treatment of the primary disease. Careful attention paid to the psychopathological elements in the behavior and speech of the patients as well as conducting detailed interviews enabled the physicians to provide a diagnosis for each mental disorder and employ efficacious treatment.

The fourth case study is different. The patient was undergoing psychiatric treatment, but the used medication was not properly selected and could have resulted in aggravating the primary disease. Elderly patients are especially susceptible to the adverse effects of medications because of their slower metabolism and reduced creatinine clearance rate, resulting in increased blood serum concentration of said medications and their tendency to accumulate. Furthermore, tricyclic antidepressants (such as amitriptyline) may cause cardiac dysrhythmias, orthostatic hypotension, and hypersedation. In the presented case study, the use of amitriptyline was an error, both due to the patient's age and the cardiac strain she was under.

\section{Rules of conduct}

In all the described cases, a preliminary diagnosis could be made by a cardiologist. Physicians of all specialties have enough expertise and competence to diagnose basic mental disorders; they must, however, pay attention to their observations concerning the patient's mental condition. Both verbal and nonverbal communication from the patient must be analyzed, along with the emotional reactions of the physician during the examination. Educating physicians put focus on finding specific somatic symptoms (heart rate, heart sound, skin appearance) and performing additional testing (ECG, enzyme levels, etc.), while impressions gained from patient interviews are treated as diagnostically irrelevant. As Kępiński observed once, this situation may be considered paradoxical, as humans learn to put more trust in singular phenomena or the results of the work of machines, rather than their own analyzer device, perfected for millions of years [12]. In order to diagnose mental disorders, one must surpass this routine and remember that a number of data obtained "by the way" may be as concrete as the results of a troponin test or an electrocardiogram.

A list of signs which should be reviewed carefully is presented below:

1. Appearance and behaviour:

- aversion to eye contact,

- sadness, little facial expression, quiet voice,

- neglect of hygiene and clothing,

- excessive vascular reactions, increased dermatographism,

- excessive sweating, trembling hands,

- apparent anxiety in behaviour and speech,

- psychomotor retardation.

2. Course of the interview:

- irritation, propensity to agitation,

- sadness, crying, sighing,

- anxious repeating of questions, constant need for reassurance,

- demonstrating disbelief in favorable information, seeking out new problems,

- memory impairments, attention impairments,

- trouble in following the flow of conversation, responses indicating cognitive impairment,

- clear problems with understanding the situation, problems with orientation,

- repeating the same issues, perseveration,

- excessively detailed utterances, excessive digressiveness.

As can be observed, the presentation of this list is much more time-consuming than the analysis of the included symptoms. Such analysis most frequently occurs automatically, and the trick is to realize the presence of the symptoms and put them together. Next, based on the totality of the physician's impressions superimposed on the patient's physical condition, the symptoms should be attributed to a group of organic (related to central nervous system injury), depressive, or anxiety disorders. Isolating organic disorders is of highest importance, as this group 
requires a slightly different approach. Central nervous system (CNS) injury may be indicated by the dominance of cognitive function disorders, affecting the precision and clarity of thought, association, and various memory functions (committing things to memory, storing and recalling memory traces). Additional indications suggesting the diagnosis of organic changes in the CNS include low left ventricular ejection fraction, advanced atherosclerotic changes in the carotid and/or cerebral arteries, and long periods of inaction.

Depressive and anxiety disorders, as well as their combinations, constitute the psychiatric problems that are most frequently encountered by patients with disorders of the circulatory system. Mood impairments and anxiety, along with their volitional consequences, are dominant. Recently published Polish studies suggest that the intensity of depression in this patient group is correlated with anxiety, understood both as a state and as a trait [13].

Combinations of organic and depressive/anxiety disorders are also common; moreover, both depression and anxiety may result from organic CNS injury. However, it should be remembered that, in view of the variety of potential pathogenetic factors, the etiology of depression and anxiety in cardiac patients is difficult to determine in an unequivocal manner.

If the gained impressions suggest the presence of depressive and/or anxiety disorders, one should pay attention to the statements and complaints of the patients, especially if the complaints are not typical of the diagnosed somatic disease.

1. "Nothing brings me joy", "nothing interests me".

2. "I'm tired and sluggish all the time".

3. "I'm useless", "my health is going downhill".

4. "I hurt all over", "nothing helps".

5. "I have no will to live, l'd rather die".

6. "I don't sleep at all, and I feel worse in the morning".

7. "Everything I do fails".

8. "I have no appetite", "I only eat in the evening or at night".

9. "I can't relax", "something bothers me all the time".

10. "I feel fear and anxiety", "I'm afraid to leave the house/ stay at home".

It is worthwhile to ask the patients about changes in their lifestyle, especially if they involve avoiding friends and colleagues, unexplained ailments in other organs, and increased sensitivity to pain, especially to previously present chronic pain.

Reaching a diagnosis is meaningful only if it results in practical consequences. The authors of this study are aware of the fact that this article is not meant for psychiatrists but for physicians specializing in somatic disorders - hence the simplified and schematic approach.

If organic CNS changes are present during the progression of circulatory system disorders, it is critical to ensure sufficient brain perfusion. Excessive or too rapid lowering of arterial pressure should be avoided; additionally, medication improving CNS perfusion and metabolism can be prescribed (piracetam, vinpocetine), keeping in mind, however, that the evidence for their efficacy is scarce.

Many more options are available in the case of depressive and anxiety disorders. In both cases, long-term action is more important than achieving a short-term tranquilizing effect. Antidepressants with anxiolytic properties are the optimal therapeutic option. Because of concomitant somatic diseases and associated pharmacotherapy, it is important to select medications that are safe with regard to the circulatory system. Most evidence related to safety and efficacy has been gathered with regard to sertraline (50$150 \mathrm{mg} /$ day) and escitalopram (5-20 mg/day), two agents belonging to the group of selective serotonin reuptake inhibitors, both listed in the Polish standards of treatment [14]. Their merits include convenient dosage - once per day, in the morning. Another therapeutic option is the use of mirtazapine (15-45 mg/day), which is a safe medication, but is treated as a second-line agent in cardiac patients, because it may cause an increase in body weight and result in potentially dangerous interactions with clonidine [15]. Because of its strong tranquilizing and sleep-inducing potential, this drug should be administered in the evening. In the case of anxiety and depression of slight intensity, it may be advantageous to use tianeptine at the fixed dose of $3 \times 12.5 \mathrm{mg}$.

The anxiolytic and antidepressant effects usually appear between the third and the sixth week of treatment, and the first efficacy assessment should take place 2-3 weeks after the start of treatment. Lack of efficacy of the above procedure should be a solid indication for psychiatric consultation.

\section{Conclusions}

Mental disorders in the context of circulatory system diseases constitute a norm, rather than an exception $[16,17]$. Some patients are unable to properly interpret the symptoms of depression and/or anxiety, instead believing them to be a result of the recurrence or worsening of the primary disease. Lack of adequate (according to the patient) reaction increases the patient's apprehension and intensifies the anxiety. In turn, the repeated visitations, complaints that do not fit the condition of the circulatory system, and the patient's discontent may result in frustrating the physician and multiplying needless diagnostic procedures. Paying attention to the psychopathological aspects of circulatory system diseases, mastering a few basic psychopharmacological techniques, and working in closer cooperation with a psychiatrist and/or psychologist may significantly improve the comfort of the patient and, last but not least, the physician [18].

\section{References}

1. Albert CM, Chae CU, Rexrode KM, Manson JE, Kawachi I. Phobic anxiety and risk of coronary heart disease and sudden cardiac death among women. Circulation 2005; 111: 480-487.

2. Haines AP, Imeson JD, Meade TW. Phobic anxiety and ischemic heart disease. BMJ 1987; 295: 297-299. 
3. Kawachi I, Colditz GA, Ascherio A, Rimm EB, Giovannucci E, Stampfer M, Willett WC. Prospective study of phobic anxiety and risk of coronary heart disease in men. Circulation 1994; 89: 1992-1997.

4. Kawachi I, Sparrow D, Vokonas PS, Weiss ST. Symptoms of anxiety and risk of coronary heart disease. The Normative Aging Study. Circulation 1994; 90: 2225-2229.

5. Todaro JF, Shen BJ, Niaura R, Spiro A, Ward KD. Effect of negative emotions on frequency of coronary heart disease (The Normative Aging Study). Am J Cardiol 2003; 92: 901-906.

6. Barger SD, Sydeman SJ. Does generalized anxiety disorder predict coronary heart disease risk factors independently of major depressive disorder? J Affect Disord 2005; 88: 87-91.

7. Szwed K, Bieliński M, Dróżdż W, Pawliszak W, Hoffmann A, Borkowska A. Zaburzenia funkcjonowania poznawczego po zabiegach kardiochirurgicznych. Psych Pol 2012; 3: 473-482.

8. Dickerson SS, Kennedy M, Wu YW, Underhill M, Othman A. Factors related to quality-of-life pattern changes in recipients of implantable defibrillators. Heart Lung 2010; 39: 466-476.

9. Piegza M, Pudlo R, Badura-Brzoza K, Hese RT. Cardiac syndrome X from a psychosomatic point of view. Arch Psych Psychoter 2009; 11: 23-27.
10. Januzzi JL, Stern TA, Pasternak RC, DeSanctis RW. The influence of anxiety and depression on outcomes of patients with coronary artery disease. Arch Intern Med 2000; 160: 1913-1921.

11. Tylka J. Czynnik psychiczny w etiologii i rehabilitacji choroby niedokrwiennej serca. Rozprawa habilitacyjna. Instytut Kardiologii, Warszawa 1994.

12. Kępiński A. Poznanie chorego. Wydawnictwo Literackie, Warszawa 2007.

13. Pawlak A, Krejca M, Janas-Kozik M, Krupka-Matuszczyk I, Rajewska J, Bochenek A. Ocena lęku i depresji w okresie okołooperacyjnym u pacjentów poddawanych rewaskularyzacji mięśnia sercowego. Psych Pol 2012; 1: 63-74.

14. Jarema $M$ (red.). Standardy leczenia farmakologicznego niektórych zaburzeń psychicznych. Via Medica, Gdańsk 2011.

15. Whooley MA. Depression and cardiovascular disease healing the brokenearted. JAMA 2006; 295: 2874-2881.

16. Matysiakiewicz J, Pudlo R. Mechanizmy łączące depresję i zdarzenia sercowe. Lęk i Depresja 2006; 11: 281-291.

17. Matysiakiewicz J, Pudlo R, Badura-Brzoza K, Matysiakiewicz I, Hese R. Gdy depresja wikła chorobę niedokrwienną serca. Psychiatr Dypl 2006; 3: 60-64.

18. Moudgil R, Haddad H. Depression in heart failure. Curr Opin Cardiol 2013; 28: 249-258. 